\title{
'You'll get nothing out of it'? The inquest, police and Aboriginal deaths in colonial Queensland
}

\author{
Mark Finnane and Jonathan Richards \\ Griffith University, Brisbane, Australia
}

Introduction

'I have the honor also to bring under your notice the conduct of Mr Poingdestre at the Enquiry held on board the Vigilant. He persisted in interrupting it with irrelevant remarks such as "What's the use of the enquiry, you'll get nothing out of it". I had several times to call him to order.' (Police Magistrate to Colonial Secretary, 14 Dec 1887, JUS/N150/87/551, in COL/A531/88/105)

The self-image of Australia as a settlement governed by the rule of law has been exposed in recent debates over the character of colonial settlement. A revisionism which questioned the historical vision of the 'quiet continent' has been noisily challenged by a counter-revisionism which characterises Australian settlement as the most peaceful of the European colonisations of the New Worlds of the Americas and the Pacific. Reviewing the balance of the positions Rowse has discerned a counterfactual that runs through Australian historiography, centred on the idea of the rule of law - was it observed in colonial conditions or abused and ignored? ${ }^{1}$ Historians studying frontiers have been confounded by the silences of the record. Much of the contemporary debate about colonial settlement centres on the significance of those silences. But even where there are scraps of evidence, hints of events for which a sustained account must involve a high degree of speculation, the reality of settlement at the boundaries of colonial rule challenges reconstruction. For

\footnotetext{
${ }^{1}$ Tim Rowse, "Historians and the humanitarian critique of Australia's colonisation," Australian Historical Association Bulletin (June, 2003), pp.
} 
Griffiths, the 'frontier is a phenomenon supremely designed to undermine the rule of law and the legal method'. ${ }^{2}$

In spite of the importance attached to the idea of the rule of law, whether as a presence or absence, the historiography of Australian settlement discloses a curious reluctance to embrace the concrete study of such a conception. The absence of accessible records has been in part to blame. The recovery and archiving of early court reports by Bruce Kercher in NSW and Stefan Petrow in Tasmania adds immeasurably to our understanding of early colonial NSW and Tasmania legal institutions. ${ }^{3}$ But even where the rule of law has been a focus of detailed attention the resulting historiography has made little impact on the dominant narratives of Australian history. ${ }^{4}$ In this context the debates centred on the violence of the Australian frontiers have proceeded with only limited reference to the history of legal institutions and practices that accompanied the extension of colonial boundaries and consolidated the process of dispossession. ${ }^{5}$

Against this background this paper examines evidence related to a legal institution, the inquest, which had an important role to play as the common law jurisdiction was established in Australia. How did such an institution operate with respect to the evidence of what was happening on the fringes of colonial settlement? In what follows we examine this question with particular emphasis on the record of cases of inquiry into the role of the Queensland police, especially the Native Police, in

\footnotetext{
${ }^{2}$ Tom Griffiths, 'The language of conflict' in S G Foster and B M Attwood, eds., Frontier conflict : the Australian experience (Canberra, 2003), p. 139.

${ }^{3}$ The on-line reports (drawn principally from early colonial newspapers) for NSW are at http://www.law.mq.edu.au/scnsw/index.htm; and for Tasmania at http://www.law.mq.edu.au/sctas/. ${ }^{4}$ The point may be made by consulting the index of almost any general history of Australia. An exception is Alan Atkinson, The Europeans in Australia : a history (South Melbourne, Vic., 1997). Alastair Davidson, The invisible state : the formation of the Australian state 1788-1901, Studies in Australian history. (Cambridge, 1991) and John Hirst, Convict Society and its Enemies: a history of early New South Wales (Sydney, 1983) are interpretations of colonial society and social formations that take law seriously. The principal specialised works dealing with the subject include David Neal, The rule of law in a penal colony: law and power in early New South Wales (Melbourne, 1991); Alex Castles, An Australian Legal History (Sydney, 1982); Bruce Kercher, An unruly child: a history of law in Australia (St Leonards, 1995) Paula J. Byrne, Criminal law and colonial subject : New South Wales, 1810-1830, Studies in Australian history. (Cambridge, England ; Melbourne, 1993); Hilary Golder, High and responsible office: a history of the NSW Magistracy (Sydney, 1991).

${ }^{5}$ See e.g. Gary Highland, 'A tangle of paradoxes: race, justice and criminal law in North Queensland, 1882-1894' in David Philips and Susanne Davies, eds., A nation of rogues? : crime, law and punishment in colonial Australia (Carlton, Vic., 1994); Susanne Davies, "Aborigines, murder and the criminal law in early Port Phillip," Historical Studies 22 (1987), pp. 313-335; ); Mark Finnane and John McGuire, 'The uses of punishment and exile - Aborigines in colonial Australia', Punishment and Society, 2001.
} 
incidents involving Aboriginal deaths. The evidence suggests that while Queensland in fact exhibited the character of a colonialism with all the institutions of a rule of law state, the government persistently failed to enforce legal accountability for the actions of those in the employment of the state. In this regard we conclude that the frontier and even those regions behind it was indeed the kind of phenomenon described by Griffiths, a place designed to undermine the rule of law and legal method.

\section{The inquest in colonial Queensland}

The central repository of official knowledge of deaths from unknown causes in

Queensland was the record of coronial inquests. As a self-governing British colony, Queensland inherited a common law system of inquests from New South Wales at its separation in $1859 .{ }^{6}$ It also inherited an administrative expectation that Aboriginal deaths be investigated - at least 22 such cases had been investigated in the northern districts during the pre-separation years from 1841 to $1859 .{ }^{7}$ Within a decade of separation from New South Wales the inquest system was altered in a crucial respect by the abolition of coronial juries, and the statutory empowerment of justices of the peace with coronial powers ${ }^{8}$. The change was pragmatic - most inquests in Queensland were already being conducted by magistrates rather than a coroner who

\footnotetext{
${ }^{6}$ The institution of inquest, originating in the King's prerogative to know about his subjects, was itself in the process of changing during the nineteenth century, being used in England as an instrument of social reform, especially of institutions (see Ian Burney, Bodies of evidence: medicine and the politics of the English inquest 1830-1926 (Baltimore and London, 2000). It cannot be said to have had quite that intense character in Australia, but as discussed below resistance by some police and settlers to the inquiring questions of stubborn coroners suggests a similar kind of potential: and see also Weaver, '’Violent Crime, Race and Common Law Justice' (unpublished, Australian Historical Association Conference, Brisbane 2002) for an emphasis on the links between the inquest and social reform in Queensland colonial culture. There does not appear to be any study of the history of the inquest in Australia - but an invaluable source for the operation of the office in Victoria, focussed on inquest records for suicide, is Simon Cooke, "Secret Sorrows: a social history of suicide in Victoria, 18411921" (PhD, University of Melbourne, 1998). See also Harold Love, James Edward Neild : Victorian virtuoso (Carlton, Vic., 1989) on the social role of an urban medical coroner in nineteenth century Melbourne; Golder, High and responsible office: a history of the NSW Magistracy, pp. 117-120 on the evolution of the office of coroner in NSW; Patricia Jalland, Australian ways of death : a social and cultural history 1840-1918 (South Melbourne, Vic., 2002), ch. 14 'Male deaths in the bush' makes extensive use of inquest and mortuary data.

${ }^{7}$ Archives Authority of New South Wales: Attorney General and Justice, Registers of Coroner's Inquests, 1834-1859. reel number 2921.

${ }^{8}$ Inquests of Death Act of 1866 (30 Vic, no. 3) - see D J R Watson, Police Court Practice: a Guide for Queensland Justices, Brisbane, 1903, pp. 281-287 for an annotated commentary. Section 1 of the act empowered a single justice of the peace with the authorities of a coroner, while section 8 empowered them with the ability to commit a person to trial. See also A/16696 (1889-1910), p. 95, p. 95 Circular 2/08, Under Secretary, Dept of Justice, to the Chairman, Bench of Magistrates, 6 May 1908, containing a legal opinion on the history of coronial jurisdiction in NSW and Queensland, especially with respect to committal powers.
} 
was rarely available in the far flung regions of the colony. ${ }^{9}$ The empanelling of juries in colonial outposts had been equally problematic - although this did not bring on a similar change in NSW until $1912^{10}$.

A Queensland justices manual outlined the circumstances and objects of an inquest in 1903 in annotations to Inquests of Death Act of 1866: 'to ascertain the cause of death, free of doubt or suspicion, so that the public may be satisfied that such death occurred in the common course of nature, and not by some unlawful violence, foul play, or culpable neglect' ${ }^{11}$. The inquest was activated by a request of two persons in writing, or by the police. In practice it would appear that in many cases the justice initiated an inquiry after hearing verbal reports of a death warranting investigation. Where available a government medical officer would be one of the many or few witnesses others would include a wide range of observers, sometimes friends or associates or relatives of the deceased. In the many Aboriginal cases we have examined it was not uncommon to obtain the evidence of Aboriginal witnesses, sometimes troopers in the Native Police, other times the kin or workmates of an Aboriginal person whose death was being investigated.

The conditions under which a death became the subject of a coronial inquiry by a magistrate were mediated by the realities of distance, denial, cover-up and subversion of justice. Reading the archives throws up compelling evidence year after year in which reports of deaths did not produce an inquest - typically because bodies were not discovered. An example from late in the period we are dealing with suggests the circumstances in which reports of deaths were not followed up. In 1888 an Aboriginal employee at Mount Merlin Station (a pastoral property near Cloncurry) stated that the manager had murdered four Aborigines and a white man. An investigation by Police Magistrate William Samwell at Cloncurry resulted in a report to the Colonial Secretary that there was no evidence of the murders. ${ }^{12}$ The terms of the report suggest

\footnotetext{
${ }^{9}$ In fact the only appointment of a coroner (Frederick Challinor) was at Ipswich.

${ }^{10}$ See eg the debates at reading of the 1866 bill, QPD, Vol III, 25 April 1866, pp. 84-5; Golder, High and responsible office: a history of the NSW Magistracy

${ }^{11}$ Watson, Police Court Practice, p. 281.

12 Telegram from Police Magistrate Samwell at Cloncurry to Colonial Secretary, 23 April 1888 in Queensland State Archives, COL/A545/88/4202. All archives references are for Queensland State Archives unless otherwise indicated.
} 
however that lack of evidence by no means implied that nothing had taken place. ${ }^{13}$ Rather such reports were consistent with local understandings of the conditions of settlement and widespread abuses of the Aboriginal people who by this stage played a crucial role in labour supply in the pastoral industry. Reporting to the Colonial Secretary the Police Magistrate had not the 'slightest doubt' of the fact that 'blacks in a great many instances are reduced to abject slavery by whips and firearms ... I am of the opinion that the Police Magistrate in these outside places should visit the various stations as aboriginal protectors ... and the Native Police [be] disbanded, ${ }^{14}$. Remote from surveillance the behaviour of white overseers and the Native Police towards Aborigines produced many incidents of which we know only an indeterminate number.

As such evidence implies, reports of violent death were capable of provoking persistent inquiry. In Queensland as elsewhere in Australia there were those who made it their mission to prompt government into action. ${ }^{15}$ Brisbane-based Alfred Davidson used his connection with the Aborigines Protection Society of London to demand police inquiry into an 1874 Brisbane newspaper report of shootings of a 'mob of blacks' at Palmer River. Invariably such a report was likely to start a round of communications between the Colonial Secretary’s Office, police and magistrates. Davidson's allegation referred to a letter appearing in the Brisbane Courier, alleging that on two different days members of a road-making expedition had shot numerous blacks. This was denied unanimously by the 16 members of the expedition in a statement given to the Cooktown magistrate. The latter concluded that 'the repressive measures used by the members of the expedition were nothing more than necessary to enable it to direct its way through' ${ }^{16}$ There was no indication that the magistrate had sought to interview Aboriginal people or other possible witnesses, to test the

\footnotetext{
${ }^{13}$ The Police Magistrate said 'If these murders happened it was two years back, when some blacks may have been shot in self defence' (COL/A545/88/4202). Two years earlier there had been a report from Cloncurry saying the manager at Mt Merlin had 'shot and wounded an Aboriginal' (COL/A454/86/843).

${ }^{15}$ A theme addressed by Reynolds in particular in a number of works: see Frontier, This whispering in our hearts;

${ }^{16}$ COL/A194/701, PM Hamilton to Col Sec 7 Apr 1874. The sixteen miners signed a statement saying 'It is true the expedition were surprised by the blacks. The Native Police were called and drove the blacks away. We heard there was one black shot in the dispersion but did not see any shot'. Their claim that 'We believe there was not a single black followed or shot by anyone' was qualified by their statement that 'We believe that had they not been dispersed in the way they were, the whole company would have been massacred' (Hamilton to Col Sec 28 March 1874 in COL/A194/74/701).
} 
credibility of the defence proffered. The ambiguity of the magistrate's reference to 'repressive measures' combined with the claim of a shooting of 'a mob of blacks' points precisely to the unresolvable character of much frontier evidence.

Even where a magistrate pursued his inquiries into a full inquest - an unavoidable obligation where bodies had been discovered - the legitimacy of the inquiry was not a given. It may be the more remarkable, given the reputation of the Queensland frontier and its hinterlands, that the efforts of magistrates to scrutinise the actions of white settlers and especially of Native Police and other police were not more frequently challenged. The potential of such challenge is evident in the case from which our epigraph is chosen. Lyndon Poingdestre was a sub-inspector of the Native Police, based at Normanton in the Gulf Country in the late 1880s. He was the very archetype of a corrupt and drunken officer of the colonial era, serving for most of the time from 1865 to 1897 - his resignation in the latter year followed a visit by senior police to his police camp where he was found living with three Aboriginal women, and five of his children. When a police magistrate held an inquest into the deaths of a number of Aborigines near the Kimberley Pilot Station in the gulf in November 1887, Poingdestre distinguished himself in continual attempts to obstruct the inquiries. 'You'll get nothing out of it', he challenged the magistrate. His attitude led both the magistrate and the government medical officer to believe that he had connived in the removal of at least three dead bodies from a location where they had been observed by other witnesses. ${ }^{17}$ Writing to the Colonial Secretary the magistrate barely restrained himself from making a charge of obstruction of justice against the police, crossing out a phrase to the effect that the 'ends of justice were to a great extent frustrated' by the police actions. ${ }^{18}$ Similar charges of obstruction of justice against the Native Police officers and associated authorities had been made by a Wide Bay District station owner in 1864 after one of his Aboriginal employees was shot dead along with another Aborigine, while in the custody of police. ${ }^{19}$

\footnotetext{
${ }^{17}$ Poingdestre was disciplined for allowing his detachment to patrol without an officer (see COL/A531/88/105)

${ }^{18} \mathrm{JUS} / \mathrm{N} 150 / 87 / 551$, in COL/A531/88/105

${ }^{19}$ See JUS/N8/64/147-8 - in this case it appears that the NP officer was removed from his post after the station owner, a JP, complained to the attorney-general about the police failing to report that they had arrested the two Aborigines concerned (see Brisbane Courier, 15 Oct 1864).
} 
In spite of these kinds of difficulties in cases threatening to implicate settlers or police inquest business in Queensland was substantial. Moreover, record-keeping was adequate enough to ensure that there remains an archive that is only a little short of complete, from 1859 on. Bureaucratic record-keeping being what it is we are not surprised to find significant numbers of inquests records (with their vital evidentiary depositions) not included in the official series - but found elsewhere in police, court, prison and colonial secretary files. In addition a scan of the Queensland Police Gazette, the official communication medium of the colonial police, enables us to identify a further range of cases where neither inquest nor court records have survived but which clearly indicate an incident involving a death that led to an inquest or other form of inquiry, in some cases at the instance of parliament, in others the result of police department initiative with a view to disciplinary proceedings. ${ }^{20}$

The great majority of more than 14,000 inquests over the 40 years subsequent to separation consisted of inquiries into accidental deaths. A review of the inquest index suggests that about 1,800 inquests involving findings suggesting violent death by self or others. ${ }^{21}$ Aboriginal people appeared in inquest records as victims, witnesses and suspects. Because our study has reasons for examining cases in which Aboriginal people were identified in any of these roles, the sample we will be discussing includes cases of non-Aboriginal deaths, in which a finding implicated an Aboriginal person as cause of death. We have identified almost 500 inquiries in which an Aboriginal person was either a victim or a suspect. Of course not all the cases in which an Aboriginal suspect was named are legitimately attributed to Aboriginal people. In the waves of fear that swept through both sides of the divide it was not uncommon for reports of deaths one day to be revised some days later, an important phenomenon that has to be remembered when reading the colonial newspapers. ${ }^{22}$

Of the record of nearly 500 cases we can summarise some important features. The first is that in the majority of inquest cases involving Aboriginal people, the inquiry was occasioned by the discovery of an Aboriginal body, or bodies. Nearly $60 \%$ of the

\footnotetext{
${ }^{20}$ Jonathan Richards, “”A Question of Necessity”: the Native Police in Queensland', forthcoming PhD thesis, Griffith University.

${ }^{21}$ Index to Inquest files, JUS series.

${ }^{22}$ For example, in December 1874 it was stated in The Queenslander that reports 'going the rounds of the Southern papers' about the murder by blacks of two brothers were incorrect, as both were still alive and working hard at the Palmer (The Queenslander, 10 December 1874, p6). Numerous other similar 'rumours' have been located in the press and are the subject of current research by Richards.
} 
inquests in this sample were investigations into the death of an Aboriginal person. A third of cases were those of 'white' persons in which a finding was made or suspicions deposed that Aboriginal people had been the assailant, while there were small numbers of other victim groups (Chinese and Melanesian mainly) also the subject of investigation.

Of the 286 Aboriginal deaths investigated, 65 were women, more than 22\% compared with about $13 \%$ of women in the whole index sample of violent deaths. The disproportion is likely to reflect the very different sex-ratios in the Indigenous and settler communities, Queensland settlers being much more likely to be male, especially in rural and frontier areas. These cases were overwhelmingly ones in which Aboriginal women living on the fringes of settler communities or in their towns had been killed by Aboriginal men - beaten by men in a drunken state, sometimes in the course of allegations about their association with other men, or as a last result of a perpetual cycle of abuse. The majority of Aboriginal male deaths investigated in the magistrate's courts of Queensland were similarly the result of mainly Aboriginal disputation, the outcome of fights over women, grog, gambling, stolen property or other causes frequently unknown.

The quality of investigation into such deaths varied - but two important points should be made. First, it was common for a large number of witnesses to be called in these cases. The inquest was a serious undertaking and its findings in the case of Aboriginal deaths would be taken seriously where the evidence was thought to justify successful prosecution. That the substantive evidence of Native Police responsibility for deaths rarely resulted in charges being laid after inquests points to the incapacity and unwillingess of government to make the rule of law a reality in frontier conditions. Second, these inquiries were ones in which it was possible for Aboriginal evidence to be taken, and occasionally it was, from at least $1860 .^{23}$ The difficulties posed by the incapacity of Aborigines to take the oath before $1876^{24}$ did not apply to the inquests, which were fact-finding inquiries, not courts of adjudication, though inevitably the disability would affect the possibility of a prosecution flowing from an inquest

\footnotetext{
${ }^{23}$ See eg JUS/N1/60/23, inquest into the death of Bobby Dick at Yandilla where a deposition was taken from Jemmy Gore ‘an aboriginal being duly sworn', who signed with 'his mark'.

${ }^{24}$ The Oaths Act Amendment Act of 1876 (40 Vic no. 10) enabled an alternative mode of taking a statement in court, but there is some doubt about how effective this was in court practice for some years, since language and interpreter issues persisted as perceived impediments to justice proceedings.
} 
finding. From the earliest days of settlement the views of Aboriginal informants were sought as part of a routine investigation into deaths. Most commonly this was through police inquiries, but on other occasions Aboriginal informants had their views recorded through the evidence of settler witnesses.

The volume of inquiries into Aboriginal death in colonial Queensland does not suggest that the frontier was a place in which there was a monolithic culture of indifference to the fact of death - whether the victim was black or white. The memorialisation of those deaths that did take place is another matter. ${ }^{25}$ Nor do the other details of the sample suggest that this surveillance of death was a phenomenon only of the metropolis, a governmental concern with the life (and death) of townspeople, contrasted with an indifference to behaviour in the harsh realities of rural and frontier regions. Indeed it is striking how few of these cases originate in the coastal and south-eastern zones, and how many in the outer reaches of Queensland over the four decades after separation. ${ }^{26}$ Only 6 inquests involving Aboriginal people were held in Brisbane in this 40 years - five of them being inquiries into the death of an Aboriginal person. Inquests into deaths involving Aboriginal people as either victims or assailants were more likely to be held in the outermost reaches of the colony than in its 'civilised' core - in Burketown, Boulia or Bowen, more than in Brisbane or Toowoomba.

This pattern of official interest in investigating death suggests something more than the reality that disproportionately greater numbers of Aboriginal people were still resident in the outer reaches of the colony. Instead we need to recognise the potential that resided in state institutions, even in their formative period and with very limited resources and even more limited communications structure, to be responsive to the fact of suspicious death. How state decision-makers acted in the light of these inquiries into death is another matter.

\footnotetext{
${ }^{25}$ See eg Jalland, Australian ways of death : a social and cultural history 1840-1918 , pp. 267-8; Griffiths, 'The language of conflict', pp. 144-7.

${ }^{26}$ In spite of judgments about the difficulty of direct control over far-flung outposts: eg Joanne Scott et al., The engine room of government : the Queensland Premier's Department 1859-2001 (St Lucia, Qld., 2001), p. 36.
} 
Published in Australian Historical Studies, no 123, April 2004, pp. 84-105

\section{The Native Police under investigation}

Were the Queensland Native Police beyond the control of the government and unaccountable to law? The evidence we review below suggests that the colonial government was always conscious of its responsibility for the actions of the QNP and repeatedly directed them to operate with regard to legal standards. But the character of governmental response to news of QNP abuses suggests that the motivation was more concern for reputation than a felt obligation for the care, as Alfred Davidson put it, of those of 'Her Majesty's subjects, who the Aborigines are[,] as much under the protection of British law as we are ourselves'. ${ }^{27}$

In considering the responsibility of the government for those incidents involving Native Police it is necessary to understand the status of that body. The Native Police had been established prior to Queensland's separation as a self-governing colony, and continued for some four decades after. Consisting of 'native' troopers under white officers, the police was a force separate from the regular Queensland Police but subject to the overall direction of the Police Commissioner. ${ }^{28}$ From the outset of Queensland's self-government the Native Police was seen as integral to the colony's self-image as a place on the very frontiers of Empire. This is abundantly clear in the Executive Council's 1861 definition of the role of the police. Responding to a Colonial Office push for the establishment of a Queensland militia, the government indicated to London its disinterest in having a local militia. There was an exception however, in respect of ${ }^{`}$

such local forces composed mainly of Natives of the various dependencies, as reasons of climate and economy, or other special circumstances, may render desirable. To the latter class belong such local forces as the Sepoy Regiments in India, the Hottentot Corps at the Cape, the Malay Regiment at Ceylon and the Native Police Corps of Qld - a Border Force which this Govt maintains for the protection of the frontier settlers. This Force costs this Colony about 17,000 Pounds annually; and may fairly be said to be (like the Frontier Police at the Cape) a contribution towards the general defence of the Empire, since the inland boundary of Qld is the boundary also of the Empire, which it is

\footnotetext{
${ }^{27}$ COL/A194/701, Davidson to Col Sec, 23 Jan 1874.

${ }^{28}$ (Qld) Police Act of 1863, 27 Vic No 11.
} 
necessary to protect from the numerous and hostile savages of this portion of Australia. $^{29}$

This characterisation of the imperial context flowed easily from the pen of Governor George Bowen, Gladstonian imperialist at the start of his long service in five different colonies. Writing to the Secretary of State for Colonies in the earliest months of his office in Queensland Bowen had already imagined the encounters between the Aborigines and colonists as part of that same historical process known to the American Indians in their encounters with 'the comrades of Columbus and of Cortez', or of South African blacks with the 'old Dutch Commandos' in more recent times ${ }^{30}$. The analogy simultaneously spoke to Bowen's perhaps grandiose sense of mission and to the reality of this latest phase of European colonisation of other worlds.

In spite of Bowen's styling of them as a local militia defending the borders of settlement from the incursions of 'hostile savages', the reality was that the Native Police was a police force, armed and dangerous, but subject throughout their existence over four decades to the authority of the Police Commissioner. This arrangement ensured that the government, in spite of its protestations at different times, was very conscious of the actions of the QNP. The force was financed generously by government (most of the money going on officers' salaries and horses), administered from the central offices of the police department in Brisbane and was subject to the accountabilities expected of other government agencies. ${ }^{31}$ Inquests formed one mechanism of accountability.

The primary object of the Native Police was the protection of settlers advancing into Aboriginal territory. In this task they were armed and authorised to use arms. The 1858 rules of the pre-separation force were revised and proclaimed in 1866 in the Queensland Government Gazette, a fact which undermines the view that their operation was secretive, beyond regulation, and conducted without oversight. Indeed we can modify Reynolds to suggest that as the colonial state in Queensland developed

\footnotetext{
${ }^{29} \mathrm{EXE} / \mathrm{E} 3 / 61 / 1$. The cost of the QNP, at $£ 17,000$ represents almost $6 \%$ of total government expenditure of £299,000 in 1861.

${ }^{30}$ Bowen to Newcastle, 10 April 1860, GOV/22, no. 33; the text is published in Bowen, Thirty Years of Colonial Government, pp. 203-205.

${ }^{31}$ Most of the NP budget was spent on the salaries of the officers, and on horses. Troopers were paid 5 pence per day, and officers feared desertions would increase when that meagre amount was reduced by
} 
its capacities, government was brought closer to the frontier, not just 'georgraphically, intellectually, morally’, but also legally, politically, administratively. ${ }^{32}$ In many respects the rules were similar to the general police rules, but focussed on management of the frontier and protection of settlement

In the performance of their duty they are distinctly to understand that their efforts should be principally directed to the prevention of crime, which will tend far more effectively towards the security of person and property than the punishment of those who have violated the laws; and the very best evidence that can be given of their efficiency will be the absence of crime in their districts. $^{33}$

The language of such a rule is directly related to the discourse of the 'new police' of the nineteenth century.

The infamous text of what has been regarded as the core rule, in which the police were directed to 'disperse any large assemblage of blacks' has been much cited, not in the context of a general discussion of the organisation of this police militia, but in order to demonstrate its aggressive role. The citation however arises from the appearance in the minutes of evidence of the 1861 Select Committee of a set of ten instructions developed by Commandant Edric Morisset. The dispersal instruction was the last. ${ }^{34}$ Within five years a much more extensive set of rules was produced. In the early 1860s, while the Queensland government was still establishing its fundamental institutions, there was a significant degree of attention to the framework of

the Executive Council to 3 pence per day in 1862: the decision was reversed (see EXE/E6/62/34 and COL/Q4/62/613).

${ }^{32}$ Henry Reynolds, With the white people (Ringwood, Vic., 1990), p. 53. There is no study comparable to that of Fels on the Port Phillip police (Marie Hansen Fels, Good men and true : the Aboriginal police of the Port Phillip district 1837-1853 (Carlton, Vic., 1988), but see especially Noel Loos, Invasion and Resistance: Aboriginal-European relations on the North Queensland frontier 1861-1897 (Canberra, 1982) for the role of policing including the Native Police. Other significant published contributions to the historiography of the Queensland Native Police include Ch. II 'Black Troopers' in Reynolds, With the white people; Raymond Evans, Kay Saunders, and Kathryn Cronin, Exclusion, exploitation, and extermination : race relations in colonial Queensland, Race and aboriginal studies. (Sydney, 1975); W. Ross Johnston, The long blue line: a history of the Queensland Police (Brisbane, 1992); Bill Rosser, Up rode the troopers: The Black Police in Queensland (St Lucia, 1990). The pre-Queensland period is extensively documented in Leslie Edward Skinner, Police of the pastoral frontier : native police, 18491859 (St. Lucia, Q., 1975).

${ }^{33}$ Queensland Government Gazette, 10 March 1866, p. 258, rule 4.

${ }^{34}$ Henry Reynolds, An indelible stain? The question of genocide in Australia's history (Ringwood Vic, 2001), pp. 101-2; see also Reynolds, With the white people, p.53; Skinner, Police of the pastoral frontier : native police, 1849-1859, pp. _312-3. 
governance of the Native Police. ${ }^{35}$ One result was the rules of 1866, which stressed a high degree of accountability of the officers for the actions of their subordinates, in the fashion of the general police -the 10 Morisset instructions of 1858 became the 62 rules of $1866 .^{36}$

In these new rules the directions for dispersal were qualified. The possibility that dispersal might mean something less than killing is clearly signalled in the 1866 rule but in a way that makes it clear why the connotation of the term was so often associated with killing ${ }^{37}$.

31. It is the duty of the officers, at all times and opportunities, to disperse any large assembly of blacks without unnecessary violence; such meetings frequently lead to depredations and murder, and mistaken kindness or misbehavior of the officers in command only inspire the blacks with sufficient confidence to commit outrages. The officers will, therefore, see the necessity of teaching the aborigines that no outrage or depredation shall be committed with impunity, but, on the contrary, that retributive justice will speedily follow the commission of crime; nevertheless the officers will be careful in receiving reports against the blacks, as it frequently happens that mistakes are made as to the identity of the aggressors. In case of any collision with the aborigines a report is to be forwarded to the Commissioner without delay.

The way in which the rules moved between a discourse of police (a 'preventive force' as it was styled in rule 17) and that of 'retributive justice' (as in rule 31) describes the space in which inquests would also be held. Rule 18, which outlined the use of force in effecting warrants of arrest, drew its rationale from the legal authorities of policing. It also cautioned officers that their actions and judgments were reviewable in legal proceedings, in which black and white were notionally equals.

When an officer sees a felony or an assault being committed, as a matter of course, he is obliged to take all offenders in charge. In every case the same law applies to blacks

\footnotetext{
${ }^{35}$ See various archive records and newspaper editorials re NP rules (COL/Q1/61/973, COL/Q2/62/480, COL/A70/65/2268 \& 2390, COL/Q3/65/877, Brisbane Courier 26 June 1865, The Queenslander 17 March 1866 \& 23 February 1867).

${ }^{36}$ Published in Queensland Government Gazette, 10 March 1866: contra Alison Palmer, Colonial Genocide (Adelaide, 2000), p. 50, 'Other than these [the 1858 instructions] there were very few rules'. Evans, Saunders, and Cronin, Exclusion, exploitation, and extermination : race relations in colonial Queensland , pp. 60-61 notes the existence of these 1866 rules but not their source; similarly Johnston, p. 92 cites the 1858 rule on dispersal but not the modified form of the 1866 'Code' for which no source is identified.

${ }^{37}$ On the connotations of 'disperse' and 'dispersal' see Richard Hall, 'Windschuttle's myths' in Peter Craven, ed., The best Australian essays 2001 (Melbourne, 2001), pp. 125-6.
} 
Published in Australian Historical Studies, no 123, April 2004, pp. 84-105

as to whites, and if the officers go beyond the law they do so at their own risk. The blacks cannot be considered as men armed for illegal purposes, because their weapons are their principal means of obtaining food.

The significance of this formalisation and extension of the rules in 1866 is not that they provided a guarantee of observance - scarcely, no more than the rules of any organisation are known to all its employees or members. Rather the rules established a mandate of responsibility, a context in which government might act against officers and troopers whose actions were excessive. The rules predicated a system of administrative control, which was much like that of the general police, including for example, at rule 54 , a diary system:

54. On the first of each month every officer in command of a detachment will send to head-quarters a copy of the diary kept by himself, according to form, stating where he has been each day during the preceding month, the duties performed, occurrences, and any steps taken in consequence, detailing what stations he has visited during the month, the state of each, the condition of the horses, and if any of them are lame or otherwise inefficient, the state of the arms, ammunition, appointments, clothing, and necessaries, the general conduct and discipline of the troopers, and if they appear to have been attentive to their duties and careful of their horses.

Against such a formal outline of police powers and duties the neglect of government in moderating the behaviour of the QNP is even more striking.

Against this background of formal regulation and accountability, what does the inquest record tell us about the actions of the Native Police and government responsibility? First we must note the contrast between the evidence of police action against Indigenous and non-Indigenous people in Queensland. It was rare indeed that police were implicated in the death of any non-Indigenous person in Queensland during the nineteenth century - to our knowledge there is not a single inquest record relating to such an event, suggesting the generally peacable character of Australian settlement behind the colonial frontiers. In spite of the state of warfare on the pastoral frontier in western Queensland in the 1890s, there were no deaths caused by police action. Other than in connection with Aborigines, it was more likely in the nineteenth century colony that police would be a victim of a shooting than the cause of it. 
Published in Australian Historical Studies, no 123, April 2004, pp. 84-105

In contrast, between 1860 and 1897 inquiries into the deaths of Aboriginal people produced at least 50 instances in which police were strongly implicated or found formally responsible. Inquest evidence is available for at least 37 cases of these cases, with other court, police or parliamentary inquiry evidence available for the remainder. In 8 cases Queensland general police were involved. ${ }^{38}$ Typically they argued either self-defence, resisting arrest or shooting an escapee. In two cases, near the end of this period, the killings involved the action of police trackers - in one case the shooting arose in a private dispute over an Aboriginal woman; in the other the tracker shot and wounded an Aboriginal man being pursued by general police near Cloncurry. In the remaining 40 cases Aboriginal people were shot by Native Police officers or their troopers. The state of the inquest records means that no formal finding is available on the filed although the Act required a form to be submitted. Other evidence including the laying of charges suggests the cogency of some inquest findings on the culpability of police actions.

\footnotetext{
${ }^{38}$ See Table and QSA: JUS/N3/61/14, JUS/N4/62/117, JUS/N30/71/103, JUS/N69/80/81, JUS/N73/81/39, JUS/N87/82/345, JUS/N151/88/32 and JUS/N253/97/251.
} 
Published in Australian Historical Studies, no 123, April 2004, pp. 84-105

\begin{tabular}{|c|c|c|c|c|}
\hline \multicolumn{5}{|c|}{ Aboriginal deaths at hands of police - results of inquests and inquiries, $1860-1897$} \\
\hline Name & Place & Date & Evidence implicating police & Known Actions \\
\hline Darky & Maryborough & $1860-02$ & Shot by NP (Bligh) & \\
\hline Tommy & Mt Flinders & $1860-12$ & Shot by NP (Wheeler) & \\
\hline Unknown & Mt Flinders & $1860-12$ & Shot by NP (Wheeler) & \\
\hline Unknown & Fassifern & 1861-01 & Shot by NP (Wheeler) & \multirow{3}{*}{$\begin{array}{l}\text { Wheeler reprimanded by } \\
\text { Select Committee }\end{array}$} \\
\hline Unknown & Fassifern & 1861-01 & Shot by NP (Wheeler) & \\
\hline Unknown & Fassifern & 1861-01 & Shot by NP (Wheeler) & \\
\hline Ex-trooper Tahiti & Dawson River & 1861-07 & Shot by NP & \\
\hline Unknown & Fairfield station & 1861-12 & Shot by NP (Morehead) & \\
\hline Unknown & Lower Dawson & $1862-12$ & Shot by NP (Johnson) & \\
\hline Tallboy & Tieryboo, Dalby & 1863-01 & Shot by NP (Carr) & \\
\hline Jemmy & Gayndah & 1863-04 & Shot by NP (Harris) & Harris chgd murder, dismd \\
\hline Wallace & Yatton & 1863-09 & Shot by NP (Richardson) & Richardson dismissed \\
\hline Governor & Maryborough & 1864-09 & Shot by NP (Brown) & Brown dismissed \\
\hline Lazy Billy & Maryborough & 1864-09 & Shot by NP (Brown) & Brown dismissed \\
\hline Unknown & Calliope & $1865-10$ & Shot by NP (Beevor) & \\
\hline Unknown female & Banana & $1866-02$ & Shot by NP (Seymour) & \\
\hline Tommy & Morinish & 1867-03 & Shot by NP (Aubin) & Aubin dismissed \\
\hline Bungaree & Tiaro & 1871-06 & Shot by Const McMullen & \\
\hline Unknown & Cloncurry & 1871-07 & Shot by WD Uhr (W) & Charges dismissed \\
\hline Billy & Gladstone & $1872-08$ & Shot by NP (Douglas) & \\
\hline Harry & Gladstone & 1872-09 & Shot by NP (Douglas) & \\
\hline Tommy & Gladstone & $1872-09$ & Shot by NP (Douglas) & \\
\hline Cassey & Herbert River & 1872-09 & Shot by NP (Sharpe) & Sharpe dismissed \\
\hline Billy & Tambo & $1872-10$ & Shot by NP (Williams) & \multirow[b]{2}{*}{ Williams dismissed } \\
\hline Chow Chow & Tambo & $1872-10$ & Shot by NP (Williams) & \\
\hline Charley & St Lawrence & 1873-07 & Shot by NP (Douglas) & \\
\hline Dickey & St Lawrence & 1873-08 & Shot by NP (Douglas) & \\
\hline Trooper Sam & Herbert River & $1874-10$ & Shot by NP & \\
\hline Corney & Miriam Vale & 1875-05 & Shot by NP (Douglas) & \\
\hline Trooper Echo & Aramac & $1875-10$ & Shot by NP (Carroll) & Carroll chd mur/dismisssd \\
\hline Jemmy & Clermont & 1876-01 & Killed by NP (Wheeler) & Wheeler charged/murder, ?ah \\
\hline Jackey & Townsville & 1877-02 & Shot by Const Macneil & \\
\hline Trooper Brandy & Normanton & $1880-02$ & Shot by Const Hedges & \\
\hline Jamie & Victoria Downs & 1881-01 & Shot by Const Cameron & \\
\hline Toby & Taroom & $1882-10$ & Killed by Const Wright & \\
\hline Spooendyke & Irvinebank & 1884-08 & Shot by NP (Nichols) & \multirow{6}{*}{$\begin{array}{l}\text { Nichols and troopers charged } \\
\text { with murder, charges failed, } \\
\text { Nichols dismissed }\end{array}$} \\
\hline Toby & Irvinebank & $1884-08$ & Shot by NP (Nichols) & \\
\hline King Billy & Irvinebank & $1884-10$ & Shot by NP (Nichols) & \\
\hline Kitty & Irvinebank & $1884-10$ & Shot by NP (Nichols) & \\
\hline Unknown female & Irvinebank & $1884-10$ & Shot by NP (Nichols) & \\
\hline Unknown female & Irvinebank & $1884-10$ & Shot by NP (Nichols) & \\
\hline Unknown & Blackall & $1884-10$ & Shot by NP (Little) & \\
\hline Unknown & Kimberley & $1887-10$ & Shot by NP (Poingdestre) & \\
\hline Unknown & Kimberley & $1887-11$ & Shot by NP (Poingdestre) & \\
\hline Unknown & Kimberley & $1887-11$ & Shot by NP (Poingdestre) & \\
\hline Tommy & Ingham & 1888-01 & Shot by Const Cannon & \\
\hline Trooper Peter & Port Douglas & 1888-09 & Shot by NP (Affleck) & \\
\hline Paddy & & $1888-12$ & Shot by NP (Carr) & \\
\hline Delta & Adavale & $1891-11$ & Killed by tracker Tommy & \\
\hline Charlie Morgan & Proserpine & $1897-03$ & Shot by Const Burke & \\
\hline
\end{tabular}

As the data in the Table suggest, the geographical pattern of coronial inquiry into 
these police killings followed the extension of settlement throughout the colony over the forty years, diminishing only in the 1890s as we would expect from the established historical accounts. That is, coronial inquiries into such deaths began in the south-east in the 1860s, moved into central Queensland in the 1870s and then into the north during the 1880s. A number of cases investigated by coroners concerned incidents where the QNP had gone on a rampage, with multiple fatalities. This was evident in the Fassifern (near Ipswich) killings in 1861, at Gladstone in 1872, at Irvinebank in 1884 and finally at Kimberley in the Gulf country in 1887. The majority of inquiries were occasioned by the discovery of a single body.

The shooting by police of Aborigines in contexts in which they were within the boundaries of settlement, rather than beyond that frontier of the colony and the Empire that had been described by the Executive Council in 1861, was usually the result of an order given by officers. The order to use arms would be explicit - as Native Police Lieutenant M. O’Connel Bligh told an 1860 inquest, 'I had given orders to my men to shoot Darky or any other blacks against whom [there were] warrants provided they could not take them. ${ }^{39}$ Once under arrest or otherwise detained Aborigines were extremely vulnerable - a number of inquests were held into deaths associated with attempts to escape from custody, and one such case appears never to have reached the stage of inquest in spite of clear police evidence. ${ }^{40}$ The freedom to shoot on sight implied by commands such as those given by Bligh was challenged from time to time by those overseeing them, by their persistent critics like Davidson, and occasionally by common citizens.

The inquest record can never be a guide to the possible scale of killings - precisely because the conditions necessary to bring matters to an inquest were so demanding. In particular the circumstances most likely to result in massacres seem highly unlikely to have resulted in attention through an inquest, since they were tantamount to actions taken in a context of war on the frontier. The archival record on the Native Police nevertheless enables attention to some cases. In March 1860 a settler at Bendemere Station in Central Queensland sought protection from Aborigines camped on his station: an instance of the dual occupancy that characterised much of the pastoral

\footnotetext{
${ }^{39} \mathrm{JUS} / \mathrm{N} 1 / 60 / 6 \mathrm{~A}$.

${ }^{40}$ COL/A39/991 - re shooting by Lt. Johnson of Native Police of an Aboriginal detainee at Dawson River (1862).
} 
frontier during these years. The request was met promptly. A report survives from Lieutenant Frederick Carr of the Native Police, advising the Colonial Secretary that he had patrolled the Station and found 'a mob of upwards of 100 all of the Upper Dawson Tribe'. Carr claimed that the Aborigines attacked them and in the ensuing battle 15 Aborigines were killed. ${ }^{41}$ Carr's openness in reporting may have saved him from government inquiry - but this was also very early in the colony's selfgovernment, preceding the attention to a framework of accountability after 1861. Carr was also the recipient of a report from another QNP officer, 2nd Lieutenant John Marlow in 1861 that implied at least 10 Aboriginal deaths in an encounter at the Maranoa River. Marlow's report used the notorious term 'disperse' in a context that denotes killing, contrasting it with the minor injuries on the police side. Facing a group of 'thirty apparently picked men ... fully armed'

I led my men to close quarters and after a sharp struggle dispersed them with a loss of ten men on their side, I was insensible for a short period during the engagement from a wound on the head, one of the men also got struck but not severely. ${ }^{42}$

Neither of these 'collisions with Blacks' as they were commonly called (Carr described Marlow's one as an 'affray'), massacres occurring in circumstances in which there appear to be no police losses, was the subject of further inquiry - neither of them are noticed anywhere in the historical literature as memorable events, being among those cases whose traces can only be found in detailed archival searching.

Later cases suggest a government more concerned to stop the killings and bring the Native Police under control of specified rules. A case in point is one we have already alluded to. In 1867 under the heading 'Barbarous outrage by the Native Police’ a colonial weekly published a chilling account by a settler who had witnessed the discovery of at least 6 Aboriginal dead and others wounded at the Morinish diggings near Rockhampton. On this occasion the government appeared to act swiftly to

\footnotetext{
${ }^{41}$ COL/A3/60/381.

${ }^{42}$ COL/A23, Marlow to Carr, letter from 'Native Mounted Police Camp, Maranoa River', 22 Oct 1861, and associated correspondence through QNP officers, Carr, Murray, Bligh to the Colonial Secretary, Herbert, who in turn referred this to the Executive Council where it was initialled by Governor Bowen. These deaths occurred in the aftermath of the Cullinlaringo massacre of 19 Europeans - for some of the antagonistic climate in which such police actions could take place see Evans, Saunders, and Cronin, Exclusion, exploitation, and extermination : race relations in colonial Queensland, pp. 52-3; Denis Cryle, The press in colonial Queensland : a social and political history, 1845-1875, UQP paperbacks. (St. Lucia, 1989), pp. 70-1.
} 
contain the damage from such a scandal, though not through judicial process - the supervising officer, whose promotion had just previously been recommended, was first suspended then dismissed. The troopers under him were transferred to another district ${ }^{43}$.

Such a response was scarcely adequate to the scale of the atrocities represented in such actions. The coronial records contain no evidence of an inquest into mass murders on this scale, nor subsequent police investigation. Rather inquests were most commonly prompted in cases affecting Aborigines who were already in some kind of relation to settler society, very often in some kind of employment - indeed this was also the context prompting the settler report of the Morinish atrocity described above, since one of the Aboriginal victims was a stockdriver in his employ. This condition for the initiation of a coronial inquiry - the likelihood that the Aboriginal body discovered or known of was a person known to and associated with the settler economy and society - suggests why inquests tend to constitute evidence at the moment of post-frontier settlement when the mechanisms of justice were being put in place. Understanding time and place is vital when one considers the cases in which Native Police actions involving multiple murder did in fact become subject to inquest or other formal inquiry.

By the 1880s, while the standing of the Native Police was questioned by many, settlers in the outer reaches of the colony still expected that the QNP would be available to clear the path for colonisation. ${ }^{44}$ In 1884 the police commissioner criticised settlers for expecting too much of the Native Police. In particular he highlighted their presumption that 'it is the duty of the Native Police to instantly pursue and shoot down offenders', in clear contrast to the police regulations that 'the same law applies to blacks as to whites and if the officers go beyond the law they do so at their own risk' (this citation being derived from words of Rule 18 of the 1866 rules $)^{45}$. At the same time it is evident that settler dispositions changed where white

\footnotetext{
${ }^{43}$ COL/E1/67/172.

${ }^{44}$ The requests for Native Police protection are too numerous to catalogue here but for examples across these decades see QSA: COL/A116/69/100 (1868: Gladstone, Port Curtis, Dalrymple, Townsville); COL/A148/70/2619 (1870: Hughenden); COL/A320/81/3869 (1881: Normanby River); COL/A754/93/13791 (1893: Cooktown).

${ }^{45} \mathrm{~A} / 40310 / 9064$.
} 
settlers were in regular contact with Aborigines who lived in camps around the towns and mining camps of the north.

These two sides of the frontier experience were evident at Irvinebank in north Queensland in 1884 when native troopers under the supervision of a white subinspector of the Native Police shot and then burnt the bodies of two women, a man and a child, among them the mother of a boy who was working for one of the local settlers. An inquest was prompted by a local justice of the peace and a large number of settlers came forward to provide evidence. In this inquiry into the Irvinebank killings the magistrate found that there was strong circumstantial evidence that the four had been murdered by Native Police troopers. The finding resulted in the dismissal of the troopers, and the suspension of their commanding officer, against whom charges of murder were laid. Yet the trial that resulted from this episode was flawed because a key Aboriginal witness was allegedly unable to provide clear evidence. ${ }^{46}$ The case depended on the circumstantial evidence provided by white settlers such as George Seaman, a clerk in a local office, who described in chilling detail the systematic harassment of local Aborigines over a number of days by the Native Police, starting with incidents he had witnessed himself:

On Wednesday the $15^{\text {th }}$ instant, I saw black troopers riding about and the blacks scattered in all directions. I went down to the town and on the allotment near Bethels I saw a blackfellow known here as Spoopindy [also known as Spoopendyke]. He was handcuffed and his feet tied together. He was fastened to a fence. He was screaming out loud. There was a black trooper in charge of him. Sub Inspector Nicholls was also there. Shortly after that the troopers led him away fastened between two horses. ${ }^{47}$

The role of non-Aboriginal witnesses in such inquests was important in prompting government and police commissioner to act against the Native Police involved - in this case Nichols was dismissed, though in the absence of evidence of his own involvement in the shootings he like so many others evaded more serious

\footnotetext{
${ }^{46}$ See A/40104, COL/A414/85/989 and COL/A419/85/2331 for details of the arrest, committal and eventual discharge of the officer and troopers.

${ }^{47}$ JUS/N110/84/511.
} 
consequences. His dismissal was endorsed by the Premier Samuel Griffith, who likewise rejected Nichols’ attempts to find his way back into the force. ${ }^{48}$

This was not the first case of inquest into Aboriginal deaths that had been sheeted home to the QNP, resulting in dismissal of the officer responsible. At Herbert River in north Queensland in 1872 the shooting and subsequent burning of the body of a twenty year-old Aboriginal woman, the 'gin' (partner) of a trooper who had deserted, led to an inquiry and direct involvement of the government. The deserting trooper Alick gave evidence at the inquest that a QNP officer, Sub-Inspector Robert Sharpe, had shot the woman after he (Alick) had tried to escape:

Mr Sharp go to Mr Atkinson's hut. Then me been frighten and me been ran . Then Simon [Sharp’s trooper] sing out him and Mr Sharp him go not up me him go ahead and gin after and him crossing creek and then shoot him gin that Sharp had revolver bullet. I see him hit same time that day. When Mr Sharp been leave I go up and see him gin. I run far back next day at daylight and me been carry him and push him in the creek and cover him up along a log and cover him up with [illegible].... Mr Sharp fire him first time along a back come out along front. That gin fall down. Then Simon come up behind and fire him carbine and put him ball along a head. Simon been come up on foot leave him horse behind. Mr Sharp along a horse when he fired. After that Mr Sharp him get off round look after one me him watch him along a scrub.

The police magistrate reported reticence among the witnesses, and initially doubted Sharp’s involvement. But his decision to hear Alick's evidence, in the presence of two other justices, led him to doubt Sharp’s denial:

Returned this morning at 6 o'clock. Have not much more than reported in my telegram of the $10^{\text {th }}$. Held magisterial inquiry. Surgeon's evidence is a young aboriginal female about 20 years of age too much burned by fire muscular fibre decomposed to ascertain cause of death. I have taken the policeman Alic's statement today in the courthouse Messrs Dalrymple and Browne sitting with me. Alic says Sharp shot first with his revolver and his trooper Simon came up and finished the gin with his carbine. I have now concluded my examination. Mr Browne says Coward

\footnotetext{
${ }^{48}$ See Roger Joyce, Samuel Walker Griffith (St. Lucia ; London ; New York, 1984). See COL/E64/84/416 and QPG, Vol 21, p257 for Nichols dismissal; also COL/A419/85/2331 when his appeal for reinstatement was rejected; and QPG, Vol 29, p360 for his arrest on false pretences charges in 1892.
} 
will be in tomorrow and he will assist me in the examination. I fear that the murder will never be brought home to the guilty person. ${ }^{49}$

Nor was it. But the weight of circumstances implicated Sharpe. At the time the Governor and the Colonial Secretary were touring the sugar plantations. When Palmer the Colonial Secretary heard of the reports implicating the police, he directed an Inspector of Police accompanying them to suspend Sharpe and 'to file a criminal information against him if I found the body and could get sufficient evidence to do so'. Sharpe was subsequently dismissed, but no criminal charges were laid. ${ }^{50}$

The killing of five Aborigines in two separate incidents in the Gladstone area in 18723 implicated the white officer in charge, Alexander Douglas, who went on to become a Chief Inspector in the Queensland Police. Douglas is likely to have avoided discipline in 1872 because he gave an account of the shooting of three blacks as justified by their attempting to avoid arrest. Yet the discursive context suggests that something else was involved, namely a determination to assert authority in an environment where European property rights were constantly being contested by the Aboriginal inhabitants. As Douglas explained to the Police Commissioner, prior to an inquest held into the 1872 killings:

If these two had escaped there is no knowing what further depredations this little band might have been committed next now that they are broken up and a lesson has been taught them I think the other blacks will profit by it and remain quiet ${ }^{51}$.

To forewarn was to be forearmed and Douglas had evidently learned early the importance of advising his superiors of such events. The fact that such inquests were only rarely rigorous inquiries helped him avoid the fate of others in his position who were dismissed - his letter implied three deaths from a limited encounter. This rate of accuracy in pursuit of alleged escapees might test the bounds of credibility, and was in some contradiction to the evidence of other depositions, yet was not scrutinised.

Douglas went on to survive another inquest the following year, and to achieve successive promotions. His actions associated with the 1873 killing of an Aboriginal

\footnotetext{
49 JUS/N35/72/218, Report of PM Sheridan to Col Sec, 15 October 1872. The body had been partly burned, although it is not clear from evidence who had attempted to burn it.

${ }^{50}$ JUS/N35/72/218; see also QPD, 1880, Vol 32:671; COL/A168/612 \& COL/A175/2337, 2342 \& 2344; COL/A175/M14; Queenslander 7/8/80
} 
man in custody were subject to coronial inquiry and the criticism of a superior, Inspector Frederick Wheeler, who noted in the files that 'ASI Douglas seems as yet not to have learnt circumspection, ${ }^{52}$. The notorious Wheeler had himself learned about circumspection after his own actions associated with the 1861 deaths of a number of Aborigines at Fassifern near Ipswich. The Fassifern deaths led not only to a widely publicised inquest but became the subject of the most famous parliamentary inquiry into the Queensland Native Police. After the report of the 1861 Select Committee, his superior officer was advised by the Colonial Secretary's office that he has 'acted upon one or two recent occasions with indiscretion and that he should be reprimanded' - this slap over the wrist was accompanied by the sanguine expectation that he would 'for the future use every exertion to perform his duty with circumspection and humanity, ${ }^{53}$. The advice was doubly warranted by the circumstances of the deaths - not only was there inquest evidence of Wheeler brandishing his gun, but the coroner's finding suggested in effect a conspiracy between Wheeler and the proprietor of the sheep run who had denied that three Aborigines had been shot on his property and sought to avoid an inquest being held, while at the same time confessing that he had called in Wheeler to see about dispersing an encampment of 'strange blacks'. ${ }^{54}$

The circumstances of Wheeler's actions at Fassifern suggest themes that might be explored for many of the incidents that implicated the Native Police and their white officers. On the one side was the presumption of almost all white settlers that the blacks should make way, with some willing to endorse murder where necessary, but not to speak openly of it. ${ }^{55}$ On the other, in post-contact conditions in rural Queensland, whites and blacks co-mingled, with Aboriginal men and women helping

\footnotetext{
${ }^{51}$ QSA: JUS/N35/72/223.

${ }^{52}$ QSA: COL/A187/73/2122; JUS/N37/73/190.

${ }^{53}$ COL/Q1/61/1318.

54 JUS N3/61/1.

${ }^{55}$ Weinholt's denial that any killings had taken place on his run was an attempt to ensure that news of NP massacres did not become public knowledge; silence was the object of Rule 19 of the Native Police Regulations, which warned officers against ‘indiscreet discussions’ (JUS/N3/61/1 and QGG, 10 March 1866). See 1890 Report from Sub-Inspector Lamond at Herberton, re Const Hansen at Nigger Creek camp: 'as a NP officer [he] had been most indiscreet in taking civilians on patrol with him and in also talking in a most reckless manner'; Lamond recommended his transfer to 'prevent a public scandal' as 'his Danish countrymen threaten all sorts of exposures': A/38828. As Loos has written, 'the colonists differentiated in their public utterances between killing Aborigines in pacified areas where it was regarded as a crime and killing Aborigines in areas where the Aborigines were "bad"': Loos, Invasion and Resistance: Aboriginal-European relations on the North Queensland frontier 1861-1897, p. 82.
} 
out around the sheep stations in a wide range of duties. ${ }^{56}$ At the 1861 Fassifern inquiry a number of people in the employ of the proprietor spoke of the fear of the Aborigines they knew around the station in the presence of the Native Police, and evidence was heard that a number had offered protection to their employees against the Native Police. ${ }^{57}$

It was this complex of attitudes and circumstances that was brought to the surface again in 1876 in a death involving this same officer Frederick Wheeler. In an atrocious incident, which has been commonly reported in the literature, but misunderstood with respect to both victim and assailants, Wheeler personally directed and participated in a severe whipping resulting in the death of a young Aboriginal man, employed at a sheep station near Belyando, and who had been found in the Native Police camp, an offence against police regulations. ${ }^{58}$ In this rare case of criminal charges being laid against a police officer of either the Native or Queensland Police, the sadistic Wheeler's actions were so public that local squatters and their employees and even a local police constable, all joined in their condemnation in evidence leading to his arraignment ${ }^{59}$. Again there was much evidence heard which suggested that the dependence of European settlers on Aboriginal labour helped shape a view that quiet and dependable Aborigines were entitled to legal protection and the benefits of justice. On the other hand the failure of whites to intervene to bring a stop to gross physical abuse of an Aboriginal man suggests the limits of their disposition. In the aftermath of the post mortem on the body Wheeler was charged with murder,

\footnotetext{
${ }^{56}$ As Gary Highland has ably demonstrated in a study of North Queensland, 'Aborigines who had been incorporated into the white economy, who enjoyed the patronage of Europeans and who were the victims of crimes committed in close proximity to white settlement received protection from the law; their counterparts on the other side of the frontier did not' (p. 137): Gary Highland, 'A tangle of paradoxes: race, justice and criminal law in North Queensland, 1882-1894' in Philips and Davies, eds., A nation of rogues? : crime, law and punishment in colonial Australia . Aboriginal History" in Overland, p29 and Johnston (1992) The long blue line: a history of the Queensland Police, p88.

${ }^{59} \mathrm{JUS} / \mathrm{CCT} / \mathrm{N} 31$. This case forms the basis of an often misleading discussion of the Native Police in Ross Gibson, Seven version of an Australian badland (St Lucia, 2002). Numerous details of Gibson's account of Jemmy's death are wrong. The evidence was not only 'hearsay' nor had the events been seen only by 'black men with no writing' (p. 56): the core of the case rested on the witnessing of the events by a white police constable, who described Wheeler not only kicking Jemmy but himself taking part on the flogging. Jemmy was not 'strung up by the heels' (p. 74), but by handcuffs on his wrists; witness Robert McGavin was not master of Banchory (p. 74) (the manager was Arthur Brown, another witness), but a stockman employing a number of Aborigines including Jemmy.
} 
and dismissed from the force, but then disappeared in mysterious circumstances and never stood trial. ${ }^{60}$

Charges against Wheeler were laid because he had been directly and visibly the agent of a homicide. This was a rare occurrence given the circumstances of most reported killings involving the Native Police in which it was almost always deposed that the black troopers had been the killers. For colonial writers like Ernest Favenc the lack of supervision of troopers lay at the heart of the atrocities committed ${ }^{61}$. Such a charge conveniently constructed the blacks as savages, only capable of being restrained by the accoutrements of civilisation, including their uniforms, and the authority of white officers. Colonial administration substantially endorsed such a position. White officers could be made the subject of discipline, or dismissed, where suspicions of their good faith or lack of competence in supervision were raised. It was scarcely likely that any other outcome would arise in a policy context in which government and the police department were constantly responding to the requests of settlers to 'disperse' gatherings of Aborigines on or near their properties. As William Hunter at Mt Abundance near Roma put it in 1863, protesting the threatened removal of the Native Police from the eastern Maranoa, 'There is a large number of blacks in this part of the country ... and they will need the presence and the dread of the Native Police force to keep them in check ' ${ }^{62}$ Only after that dread had done its work could settlers feel secure in a normality described by Bowen in his 1860 letter to the Secretary of State for Colonies, a state in which ' $[\mathrm{t}]$ he milder natives sink ere long into the condition of well-led dependents of the colonists, and in the course of a few years no danger remains to be apprehended from them beyond some isolated acts of robbery or revenge'. ${ }^{63}$

\section{Conclusion}

In 1861 the Queensland Executive Council saw the frontier as 'the boundary also of the Empire' - beyond it were the 'numerous and hostile savages of this portion of Australia'. Protecting the settlers against the 'savages' was the explicitly mandated function of the Native Police. Their role was controversial throughout the period of

\footnotetext{
${ }^{60}$ Despite being charged with wilful murder, Wheeler was granted bail by the Court and absconded from Queensland.

${ }^{61}$ Ernest Favenc, The history of Australian exploration from 1788 to 1888 : compiled from State documents, private papers and the most authentic sources of information (Sydney, 1888).

${ }^{62}$ QSA: COL/A49/64/41, Z/5691.
} 
their operations in Queensland. Far from being unregulated in remote outposts of the colony the evidence suggests that their actions were the object of continuing, daily, regulation from Brisbane. Did this mean that they were always rendered accountable for their actions? Scarcely - there is significant evidence that, even when they were considered blameworthy, the worst they could expect was dismissal. There were only four prosecutions, all unsuccessful: Brown (1864) for the unexplained and unreported deaths of two men, Wheeler (1876) for a sadistic homicide witnessed by other police and settlers, Carroll (1876) for a murder of one of his own troopers, and Nichols (1884) which also arose in circumstances where there appeared to be a large number of settlers prepared to speak out.

The evidence briefly surveyed above constitutes an instructive lesson in the mechanisms of colonial government. In spite of the recent outbreak of denialism in Australian political and intellectual debates the historical records retain irrefutable evidence of the violence of the process of dispossession in the colonial era. Paradoxically this remains the case precisely because so much of the evidence brings it home to us just how implicated was government in seeking both to establish mechanisms of justice that would legitimate and discipline the process of colonisation, and to avoid the presumptive equality of the rule that black and white were equal. In our view the number of killings remains a moot point. What is clear is government responsibility, and government failure to act on knowledge obtained through lawful processes.

'The rule of law', it has been said, 'presupposes a lot to be effective and a lot to be good'. ${ }^{64}$ The instruments of government in Queensland in the colonial period were advanced. They were above all colonial - intended to provide a system for the effective and long-lasting plantation of settlers on Indigenous lands. To establish the boundaries of what this particular colonisation implied for the dispossessed it is necessary to understand the authorities and constraints which prevailed in the process of government extension of rule over greater and greater areas of land. On the one hand the executive government established something best described as a police militia, with white officers deployed in command of locally recruited Indigenous

\footnotetext{
${ }^{63}$ Bowen to Newcastle, 10 April 1860, GOV/22, no. 33.

${ }^{64}$ Martin Krygier and Robert van Krieken, 'The character of the nation’ in Robert Manne, ed., Whitewash : on Keith Windschuttle's fabrication of Aboriginal history (Melbourne, 2003), p. 103.
} 
troopers. Subject to the authority of the general police force, which had itself been established largely on the Irish model, the Native Police was expected to exercise discipline in the management of the border conflict between settlers and Indigenous peoples. The construction of the Aborigines as savage and barbarous was held to justify the use of extreme force where necessary. There was to be a limit to this use of force however and this limit marks out the boundary of the colonising state, describing its self-image as a bearer of good government. That limit was especially found in the early establishment of inquests as a mechanism of inquiry into unexplained death, including of Aborigines at the hands of the police.

The inquest was simultaneously a statement of this colony's rule under law, the common law of the settlers, and a witness to the way in which the frontier confounded expectations of a civilised process of settlement. The fact that state mechanisms of justice would bring to light cases of multiple killings in circumstances that were consistent with widely publicised and compromising discourses of colonial violence directed at Aboriginal people is telling both of a colonial reality and of a discomfort. The reality is that even under conditions of some visibility there were police and settlers who could behave with excessive and often fatal violence. Beyond the horizon of state visibility there were continuing stories of worse violence. Within the archival record itself there remains a large number of cases where state officials reported or admitted their own role in multiple murders, never the subject of official inquiry, by inquest or parliament.

The absence from the inquest record of inquiries into deaths occasioned by settlers in the contact zone has a variety of possible explanations, all of them underlying disputes about the record of Australian settlement. But a critical one is the lagged formation of the state under conditions of colonialism. Our evidence suggests that the inquest followed not far behind the advance of settlement, but the frequent call of settlers for police protection shows just how common was the phenomenon of settlement proceeding in advance of an effective structure of state administration. Once state institutions were in place other factors are likely to have limited the likelihood of settlers leaving visible their actions against Aborigines or reporting each others' misdeeds - chief among them being a consciousness of what had happened after Myall Creek. 
The archived inquest record is a remnant of what happens at that time of transition when Aboriginal people were being brought into the colonial fold, as dispossessed but now useful workers in the pastoral and household economies. In this context there was also a continuing dual occupancy, in which Aboriginal people would seek resources from the settler economy, by force, or exchange, while sustaining their own kin and culture. This judgment is not simple retrospectivity. Such a process was visible to the people of those time - even to those as hostile as the Fassifern proprietor John Hardie, who wanted the strange blacks dispersed in 1860, but yet acknowledged the reality of another way of looking at the world in his otherwise evasive evidence about the deaths on his station:

A blackfellow asked me if he might burn the body of the blackfellow. He said he was a relation. I told [him] he could do as he liked. I do not know whether the blacks were in the habit of burning or burying their dead. The black who asked to burn the body was doing some work for me on the station and he wanted my permission to allow him to go and I permitted him ${ }^{65}$.

Such evidence, when taken with its origins in a coronial inquest, captures the colonial moment, one in which the rule of law was both agent of dispossession and its potential critic. The inquest, an ancient institution of the common law, sought explanations for suspicious as well as accidental death - but in colonial conditions was an ineffective medium of accountability, in a state where the completion of dispossession and securing the boundaries of the Empire was the first task of government.

Atkinson, Alan. The Europeans in Australia : a history. South Melbourne, Vic.: Oxford University Press, 1997.

Burney, Ian. Bodies of evidence: medicine and the politics of the English inquest 1830-1926. Baltimore and London: The Johns Hopkins University Press, 2000.

Byrne, Paula J. Criminal law and colonial subject : New South Wales, 1810-1830, Studies in Australian history. Cambridge, England ; Melbourne: Cambridge University Press, 1993.

Castles, Alex. An Australian Legal History. Sydney: Law Book Co., 1982.

\footnotetext{
${ }^{65}$ JUS/N3/61/1. Aborigines at Fassifern shot by Native Police (Wheeler) 24/12/1860.
} 
Cooke, Simon. "Secret Sorrows: a social history of suicide in Victoria, 1841-1921." PhD, University of Melbourne, 1998.

Craven, Peter, ed. The best Australian essays 2001. Melbourne: Black Inc., 2001.

Cryle, Denis. The press in colonial Queensland : a social and political history, 18451875, UQP paperbacks. St. Lucia: University of Queensland Press, 1989.

Davidson, Alastair. The invisible state : the formation of the Australian state 17881901, Studies in Australian history. Cambridge: Cambridge University Press, 1991.

Davies, Susanne. "Aborigines, murder and the criminal law in early Port Phillip." Historical Studies 22, no. 88 (1987): 313-335.

Evans, Raymond, Saunders, Kay, and Cronin, Kathryn. Exclusion, exploitation, and extermination : race relations in colonial Queensland, Race and aboriginal studies. Sydney: Australia and New Zealand Book Co., 1975.

Favenc, Ernest. The history of Australian exploration from 1788 to 1888 : compiled from State documents, private papers and the most authentic sources of information. Sydney: Turner \& Henderson, 1888.

Fels, Marie Hansen. Good men and true : the Aboriginal police of the Port Phillip district 1837-1853. Carlton, Vic.: Melbourne University Press, 1988.

Foster, S G, and Attwood, B M, eds. Frontier conflict : the Australian experience. Canberra: National Museum of Australia, 2003.

Gibson, Ross. Seven version of an Australian badland. St Lucia: UQP, 2002.

Golder, Hilary. High and responsible office: a history of the NSW Magistracy. Sydney: Sydney University Press, 1991.

Hirst, John. Convict Society and its Enemies: a history of early New SouthWales. Sydney: Allen \& Unwin, 1983.

Jalland, Patricia. Australian ways of death : a social and cultural history 1840-1918. South Melbourne, Vic.: Oxford University Press, 2002.

Johnston, W. Ross. The long blue line: a history of the Queensland Police. Brisbane: Boolarong, 1992.

Joyce, Roger. Samuel Walker Griffith. St. Lucia ; London ; New York: University of Queensland Press, 1984.

Kercher, Bruce. An unruly child: a history of law in Australia. St Leonards: Allen \& Unwin, 1995.

Loos, Noel. Invasion and Resistance: Aboriginal-European relations on the North Queensland frontier 1861-1897. Canberra: ANU Press, 1982.

Love, Harold. James Edward Neild : Victorian virtuoso. Carlton, Vic.: Melbourne University Press, 1989.

Manne, Robert, ed. Whitewash : on Keith Windschuttle's fabrication of Aboriginal history. Melbourne: Black Inc. Agenda, 2003.

Neal, David. The rule of law in a penal colony: law and power in early New South Wales. Melbourne: Cambridge University Press, 1991.

Palmer, Alison. Colonial Genocide. Adelaide: Crawford House Publishing, 2000.

Philips, David, and Davies, Susanne, eds. A nation of rogues? : crime, law and punishment in colonial Australia. Carlton, Vic.: Melbourne University Press, 1994.

Reynolds, Henry. An indelible stain? The question of genocide in Australia's history. Ringwood Vic: Viking, 2001. . With the white people. Ringwood, Vic.: Penguin Books, 1990.

Rosser, Bill. Up rode the troopers: The Black Police in Queensland. St Lucia: UQP, 1990. 
Published in Australian Historical Studies, no 123, April 2004, pp. 84-105

Rowse, Tim. "Historians and the humanitarian critique of Australia's colonisation." Australian Historical Association Bulletin, no. 96 (2003): 83-89.

Scott, Joanne, Laurie, Ross, Stevens, Brownwyn, and Weller, Patrick. The engine room of government : the Queensland Premier's Department 1859-2001. St Lucia, Qld.: University of Queensland Press, 2001.

Skinner, Leslie Edward. Police of the pastoral frontier : native police, 1849-1859. St. Lucia, Q.: University of Queensland Press, 1975. 
Published in Australian Historical Studies, no 123, April 2004, pp. 84-105 